N.M.S. Faria

Mechanical Engineering Departmen ISEP - School of Engineering, Porto

Portugal

R.D.S.G. Campilho

INEGI - Institute of Science and Innovation in Mechanical and Industrial Engineering Porto, Portugal

Mechanical Engineering Department ISEP - School of Engineering, Porto Portugal

F.J.G. Silva

Mechanical Engineering Departmen ISEP - School of Engineering, Porto

Portugal

\section{L.P. Ferreira}

Mechanical Engineering Department ISEP - School of Engineering, Porto Portugal
Concept and Design of Automated Moving Device for Healthcare Equipment

The physical wear of health professionals arises mainly from the movement of people with reduced mobility, transport of stretchers, hospital beds and hospital carts. There is a lack of equipment that helps these professionals to move patients in hospital beds or stretchers. This work aims to design an equipment that removes health professionals' function of moving patients from beds to stretchers, being able to move patients around the hospital in a bed. Added to this challenge was the diversification of models of hospital beds, making it necessary for the equipment to adapt to all beds. The design process included several finite element method analyses to validate the structure, and also a structural optimization, to reduce costs and reduce the weight of the equipment. This work successfully designed an optimized automated solution that can improve working conditions in the healthcare industry.

Keywords: Healthcare equipment; Finite element method; Hospital bed movement; Mechanical design; Structural optimization.

\section{INTRODUCTION}

The existence of reserved spaces for curing diseases dates to the ancient ages. Since that time, researchers seek to gain knowledge about the ailments that the human body suffers [1]. In addition to medical knowledge, assistance and care to the patient are very important concepts. Whenever these services are required, they should be accomplished by professionals who are not susceptible to making mistakes, thus avoiding harming patients [2]. The physical wear of health professionals, i.e., nurses and health assistants, arises mainly from the movement of people with reduced mobility, transport of stretchers, hospital beds and hospital carts full of medical equipment, instruments, and medicines [3]. All these activities become exhausting over the years, due to the equipment weights to be moved, which makes them difficult to maneuver and increases the required effort to exert. In addition, more than one person may be necessary to move them, so that they do not hit the walls, other equipment, or people. When hospitals or healthcare centers are overcrowded, often these professionals move the equipment on their own, so that they can provide a faster response to patients. These actions promote musculoskeletal injuries, which are sometimes so severe that the professionals need to be medically discharged [4]. Therefore, there is an additional workload on other health professionals, namely in the handling of heavy equipment, which is increasingly performed by only one person, since there are fewer professionals who can assist in the movement. In this aspect, there is a lack of equipment that helps these professionals to carry out

Received: March 2021, Accepted: May 2021

Correspondence to: Prof Raul Campilho, Department of Mechanical Engineering, ISEP - School of Engineering, Porto, Portugal,

E-mail: raulcampilho@gmail.com

doi:10.5937/fme2103598F

(C) Faculty of Mechanical Engineering, Belgrade. All rights reserved their work with less physical effort, specifically for the movement of patients in hospital beds or stretchers within the facilities [5]. This equipment would bring advantages to the professionals, by reducing their overload, and for the institutional management, by cancelling the need to hire new employees, when others are on prolonged medical leave due to the previously mentioned injuries. With such a system, the transfer of patients from beds to stretchers (which are easier to move) is also no longer necessary [6].

On account of all these issues, the hospital equipment industry has received more investment over the decades, following the developments in the fields of medicine, nursing and medical diagnostic techniques [7]. In this sense, the need for equipment's improvement and optimization used in this industry has been notorious, as the technological advance requires it. This advance also exists for the improvement of employees' working conditions, including the implementation of equipment to assist their tasks, reducing the physical effort to perform the tasks. According to the World Health Organization (WHO) [8], the world average that governments attribute to health is $10 \%$ of gross domestic product (GDP), which are distributed by medicines, health care, equipment, among others. The 10 countries that most develop health equipment correspond to $78.6 \%$ of global investment, corresponding to $157.1 \times 10^{3}$ million euros. It can thus be concluded that there is a major investment on the part of the countries, mainly of the more developed ones, in creating equipment of support and diagnosis to the patient.

Currently, research works on the design of movingaid systems in the healthcare field are extremely scarce, and all the found information focuses essentially on the ergonomics and standardization of equipment for the safety of healthcare professionals and patients $[9,10]$. Previous studies [11, 12] showed that, in a hospital environment, as in any other environment, the 
equipment must be used with care. Inefficient use by the healthcare professional may have different origins and consequences:

- Poor handling of the equipment can cause injury to the patient;

- Anxiety and stress of the health professional decreases the ability to care for the patient;

- Inability to use the equipment harms the patient in his treatment.

To avoid this type of situation, it is necessary that the equipment is designed for the longest lifespan possible, having an ergonomic design, and adapting the equipment to the user, the task and the environment [13]. According to Thompson [14], in the case of anesthetic equipment, the design must take into account the position of the alarm signals, so that the operator can see them during their use. Maintenance and future improvement of the equipment is also something to pay attention to. For the correct use of the equipment, the user must test the equipment so that during its use it does not harm the patient. Therefore, the user will make a check of his knowledge regarding the operation of the device, while doing this verification. For Tonks [15], the industry is at the forefront of healthcare services in improving the design of its equipment to protect its users. The lack of uniformity of equipment for the same purpose causes stress in the health professional. Using similar equipment, but with a different arrangement of instruments, in emergency situations, can make handling difficult and endanger the health of the patient. This author gives the case of ambulances of the national health service of England, where 40 different designs were found. An ambulance change, in this case, could cause stress to the paramedic due to the different arrangement of the instruments inside the ambulance, as they do not know where to find the necessary material to help the victim. In addition to medical equipment, hospitals have equipment for storage, cleaning, transportation, among others. In 2002, Das et al. [16] studied the case of a hospital food cart, so that the equipment had a more ergonomic design and, therefore, lessened the problems caused by its movement. McAnyana et al. [17] described the mechanical design process of the supporting structure for the XR-646 Xray Medical Equipment, so that it can support the overhead tube support (OTS). This process received help from the General Electric Healthcare (GEHC) equipment specification. All the design process, including drawing and layout, material selection for the structure and component sizing, were accomplished using the Autodesk Inventor software, which enabled virtually testing the structure and perform displacement and stress analysis, and thus selecting the geometry that provides the adequate support for the OTS. Kurebwa and Mushiri [18] performed a literature review on healthcare issues in medical emergencies, with emphasis to the transport vehicles. Issues like autonomous driving and respective implications on safety are addressed. A review was also performed regarding the robotization of surgical procedures. It was discussed that robots have a large potential to surpass human limitations in surgical procedures, and that advanced artificial intelligence (AI) and robotic systems can improve safer mobility in the future. Also, in some cases, the human-robot collaboration can help reducing injuries in medical emergency equipment.

This work was developed in partnership with an engineering design company, which realized that there was a need to create an equipment that would help hospitals to have fewer workers to be on sick leave due to the handling of heavy loads, leading to the extra burden of their replacement. The objective was to design an equipment that would remove the health professionals' function of moving patients from beds to stretchers, being able to move patients around the hospital in a bed, without having to exert force to move the bed. Added to this challenge was the diversification of models of hospital beds, making it necessary for the equipment to adapt to all beds. The design process included several finite element method (FEM) analyses to validate the structure, and also a structural optimization, to reduce costs and reduce the weight of the equipment.

\section{METHODS}

\subsection{Problem characterization}

As formerly mentioned, this work arises from the request of an engineering design company, aiming to design an equipment that would facilitate handling of heavy loads, namely moving hospital beds inside the healthcare facilities. Actually, in a preliminary survey with company clients (mainly hospitals), the highlighted problem consisted of many health professionals with health problems associated with the handling of loads, i.e., patients from beds to stretchers and vice versa. As in several studies in the nursing field indicate, e.g. reference [19], this movement requires a major effort on the part of the professional. Likewise, the simple movement of the hospital bed also causes efforts on the back of those who move.

The high combined weight of the bed/stretcher and patient set makes it very difficult to maneuver. Therefore, the company decided to design an equipment that removes the need for the professional to undertake these efforts. With this equipment, the effort to maneuver the hospital bed will be reduced, since all the effort will be made by a motorized wheel. Currently, there are hospital beds with a fifth wheel, motorized, which allows moving the beds with less effort. However, it is not very profitable to have this mechanism in all beds, because it is not used in most of time. Thus, the need arose to make this motorized wheel profitable. By associating the motorized wheel with a portable structure, the question of its profitability will be increased, since with a motorized wheel it will be possible to serve more than one bed.

\subsection{Design goals}

In view of the hospital panorama described, there is a possible improvement in working conditions for health professionals who spend their days handling heavy loads. Thus, the main objective if this work is the design of an equipment that helps the movement of hospital 
beds and stretchers. With the main objective defined, the following sub-objectives can be outlined as well:

- Define the concept of the product to be developed, in conjunction with potential customers;

- Check customer needs for this product;

- Be aware of the costumers' construction restrictions;

- Analysis of similar products on the market;

- Proposal of different solutions that meet the requirements, to select the best solution;

- Choice of materials and manufacturing processes;

- Structural design and FEM analysis for optimization.

\section{PRELIMINARY DESIGN}

\subsection{Brainstorming}

Based on existing equipment, different queries were discussed by the design team before choosing the design solution:

- It was concluded that different couplings are required between the equipment and the hospital beds, namely: elevate the bed by the headboard/footboard; lift the bed directly by grabbing its wheels; and lift the bed by the structure next to the wheels;

- Another issue to address concerns the possibility of lifting or simply coupling of the bed to the equipment. The first option excels in giving higher steering control to whoever moves the equipment, since the wheels of hospital beds are all swivel. The simple coupling solution allows for a less stiff structure because no bed load will be applied to the equipment structure;

- As for the maneuverability of the equipment, the designer can choose to use the driving wheel as a directional wheel, removing the effort from the operator. It is also possible to simplify the equipment if there is no steering system, by placing rotating wheels. In this case, the operator will have to apply additional load to steer the equipment. In this case, the driving wheel would be fixed and would have to be positioned between the rotating wheels and the hospital bed;

- The structure of the equipment can be built based on bent and welded sheets to provide stiffness. However, this solution becomes more complex for design purposes. Another possibility is the use of welded tubular profiles, which gives good stiffness, creating a simple structure.

From the conclusions derived from this process, two solutions were proposed, presented in the next sections.

\subsection{Solution A}

The first concept (Figure 1) is the most compact and makes the equipment easy to store, allowing the passage of people and other equipment when left in a corridor. In Figure 1 (b), it is observed that the equipment would have a slope, such that the grip's displacement would not be perfectly vertical. This tilting would keep the equipment stable when lifting the bed, putting the center of gravity (CG) of the equipment under operation between the swivel wheels and the driving wheel. a)

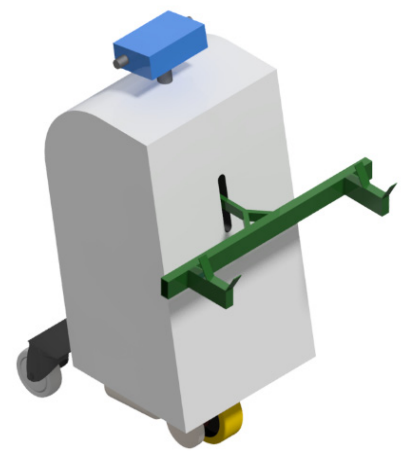

b)

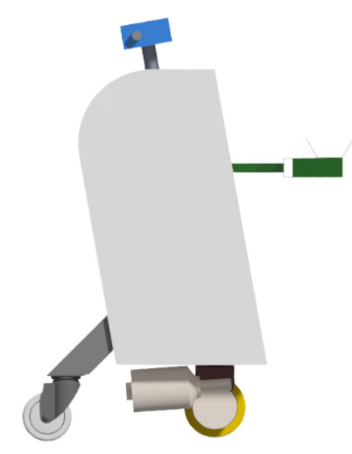

Figure 1. Isometric (a) and side views (b) of solution A.

As there are only three supporting points to the ground (two swivel wheels and a driving wheel), and they are not far apart, a mechanism was designed next to the swivel wheels that moves them away of the driving wheel with the increased load applied by the bed. This mechanism is accomplished with the introduction of a compression spring, whose operation is shown in Figure 2. With this mechanism, the equipment will further tilt, allowing the equipment's CG to move to a position farther from the bed, giving stability to the equipment. a)

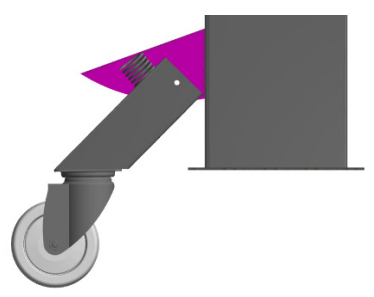

b)

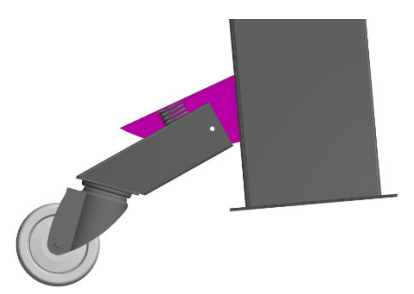

Figure 2. Swivel wheel support movement of solution A: initial spring position (without bed load) (a) and final spring position (with bed load) (b).

The structure of this solution (Figure 1) is based on bent sheet metal construction (the bends aim to provide stiffness to the structure under load). To move the equipment's arm, an electric actuator was thought of, as it is the solution that provides the best mobility, using only batteries as power source. The arm movement is done inside a $\mathrm{C}$ profile. Inside the profile, nylon blocks ensure optimal sliding. Nylon is a material with a low friction coefficient when it has reduced roughness and assures smooth movement inside the guide. The drive wheel is attached to the frame without the freedom to rotate around its vertical axis. Thus, the user will have to make an additional effort so that the equipment describes curved paths. Despite the need for back muscle effort, this is much less than the effort made by direct movement of the bed [20].

\subsection{Solution B}

Conversely to the former design, this solution (Figure 3) includes four swivel wheels, with further separation from each other to give more stability to the equipment, 
plus the driving wheel. This solution increases the equipment's stability by enlarging the spacing and increasing the number of ground supports, preventing losing the static balance in only three supports. It is thus considered that the two additional swivel wheels near the driving wheel help to this stability.

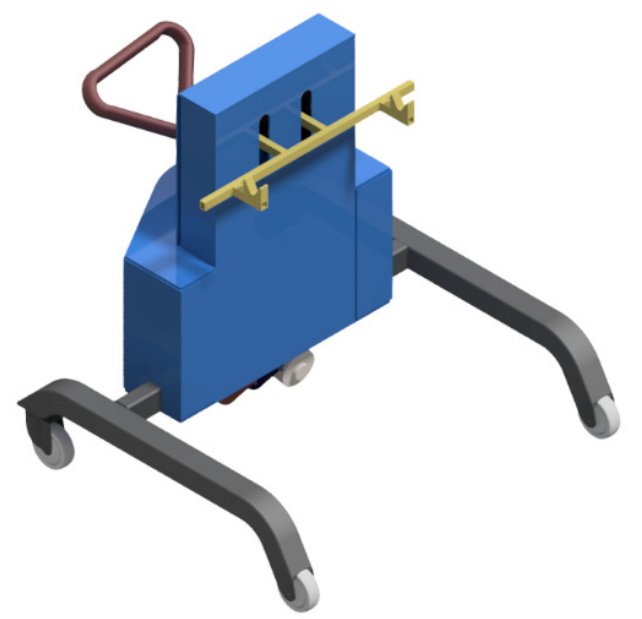

Figure 3. Isometric view of solution B.

For the frame design (Figure 4), a solution based on rectangular profiles was selected, which makes the structure robust and cheap. Moreover, these profiles have high availability in the market, which expedites fabrication. For the lifting arm movement, also in this solution an electric actuator was considered, being led by guides and ball slides. To fix the guides, the use of European Standard (UPE) profiles was equated.

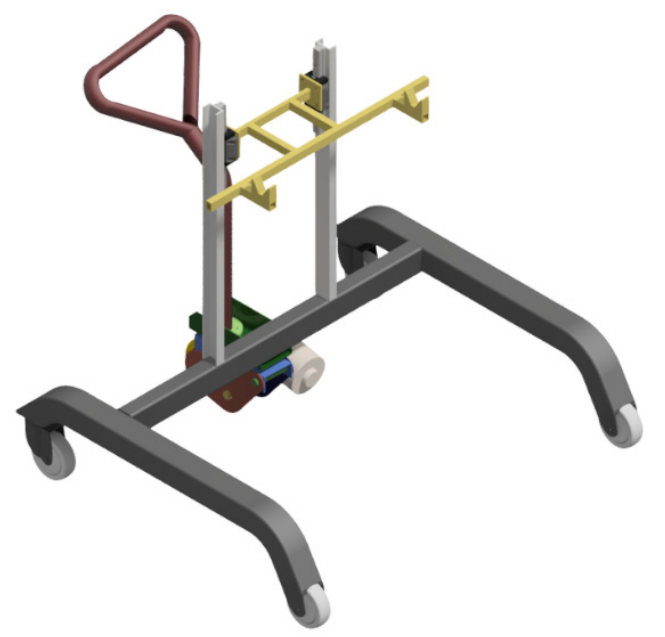

Figure 4. Isometric view of the structure and some components of solution $B$.

The driving wheel, coupled to the four swivel wheels, is one of the five ground supports of the equipment. This wheel has a compression spring to enable a scissors movement to its structure, forcing the wheel to be in permanent contact with the ground and allowing it to absorb shocks (Figure 5). Although it is not represented in this figure, an angular worm gear motor will be attached to the wheel. This type of motor is compact, makes the speed reduction possible, and allows the wheel rotation without the motor becoming unprotected by the armor, thus not touching the user's feet. To maneuver the equipment, a device identical to an electric pallet truck handle was selected. a)

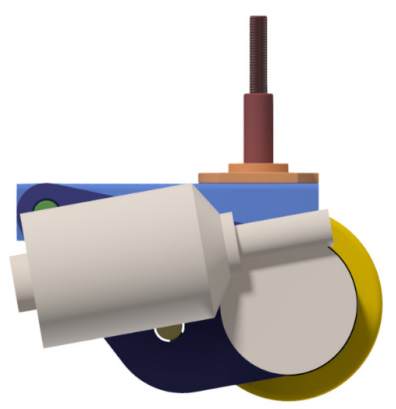

b)

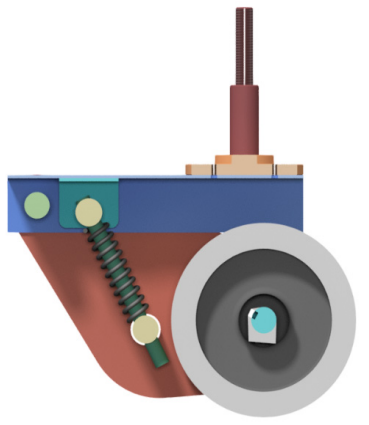

Figure 5. Side (a) and section views (b) of the drive wheel structure of solution $B$.

\subsection{Design selection}

In view of the presented solutions, an analysis of the positive and negative points of each was made. The results of this analysis are schematized in Table 1.

Table 1. Comparative evaluation of both solutions.

\begin{tabular}{|c|c|c|}
\hline & SOLUTION A & SOLUTION B \\
\hline $\begin{array}{l}n \\
0 \\
0 \\
0 \\
0 \\
0 \\
0 \\
0 \\
0\end{array}$ & $\begin{array}{l}\text { Cheaper guide system; } \\
\text { Compact (when not } \\
\text { used, it occupies less } \\
\text { space). }\end{array}$ & $\begin{array}{l}\text { Less complex and } \\
\text { stiffer structure; } \\
\text { Steering drive wheel } \\
\text { with damping system; } \\
\text { higher stability, even } \\
\text { when under load; } \\
\text { Smoother guide } \\
\text { system. }\end{array}$ \\
\hline$\sum_{\substack{n \\
0}}^{2}$ & $\begin{array}{l}\text { Absence of steering } \\
\text { wheel; } \\
\text { Guide system with } \\
\text { more friction; } \\
\text { More complex } \\
\text { structure; } \\
\text { Equipment can become } \\
\text { static unbalanced when } \\
\text { loaded. }\end{array}$ & $\begin{array}{l}\text { Complex driving } \\
\text { wheel mechanism, } \\
\text { leading to higher costs; } \\
\text { More expensive guide } \\
\text { system; } \\
\text { Unappealing design. }\end{array}$ \\
\hline
\end{tabular}

Based on all presented advantages and limitations of both solutions, it appears that solution B is the most suitable to this purpose. However, it should be noted that the guide system, for the intended purpose, does not need to slide as smoothly as it occurs with linear ball guides. Actually, a guide rail made of $\mathrm{C}$ profile and nylon-coated blocks will have the intended sliding effect at a lower price. Under these conditions, the $C$ profile, which serves to guide the actuator, is too a structural element. Thus, it will have a double functionality, in opposition to the UPE profile of solution A, which only has a structural function.

\section{DESIGN}

\subsection{Overview of the final solution}

After selecting the solution for the hospital bed movement system, it was modelled and optimized. The final design is presented in Figure 6: isometric (a) and side views (b). 


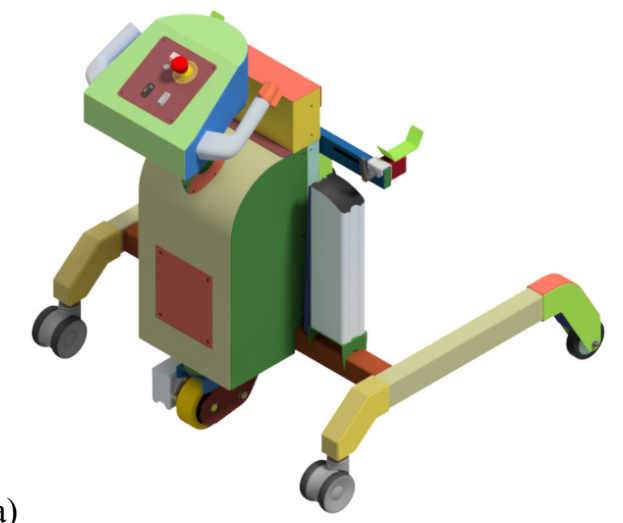

a)

b)

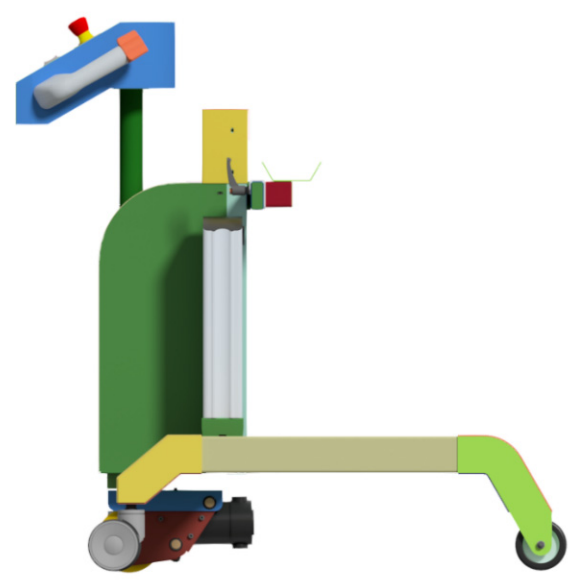

Figure 6. General representation of the final designed equipment: isometric (a) and side views (b).

Comparing the model shown in Figure 6 with the preliminary design (Figure 3), a slight difference was found in the armor and in the steering system. As the batteries have an eye-catching design, they will remain visible, which also helps to replace the batteries and improve aesthetics, as it is intended an equipment with a less industrial design. This involves a reduction in the volume of the armor, which implied the removal of the batteries from its inside. The armor will then cover only the structure of the bed elevation system, the steering, and the controller.

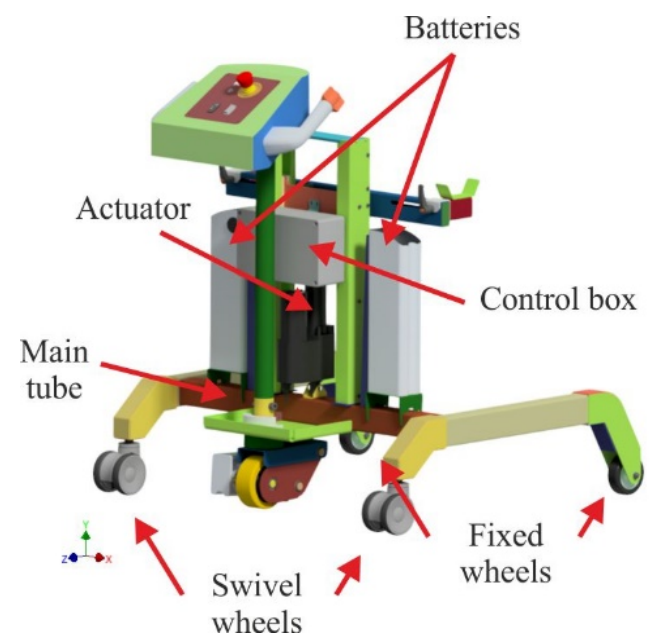

Figure 7. Main components of the designed equipment.

Figure 7 shows that all main components are resting on the main tube of the base frame. This will be where all the loads will be concentrated, so it has to be robust to withstand the entire load that will be subjected to it. To fix the driving wheel in place, it was necessary to insert a plate (welded to the main tube), which will also serves as the bottom of the armor. Access to the inside of the equipment from the bottom is also not allowed. As the driving wheel will also be a support, this plate will be a structural element. The main systems of the equipment are described next.

\section{- Lifting system}

The lifting system consists of three parts (Figure 8): the actuator, the guidance system, and the lifting arm.

a)
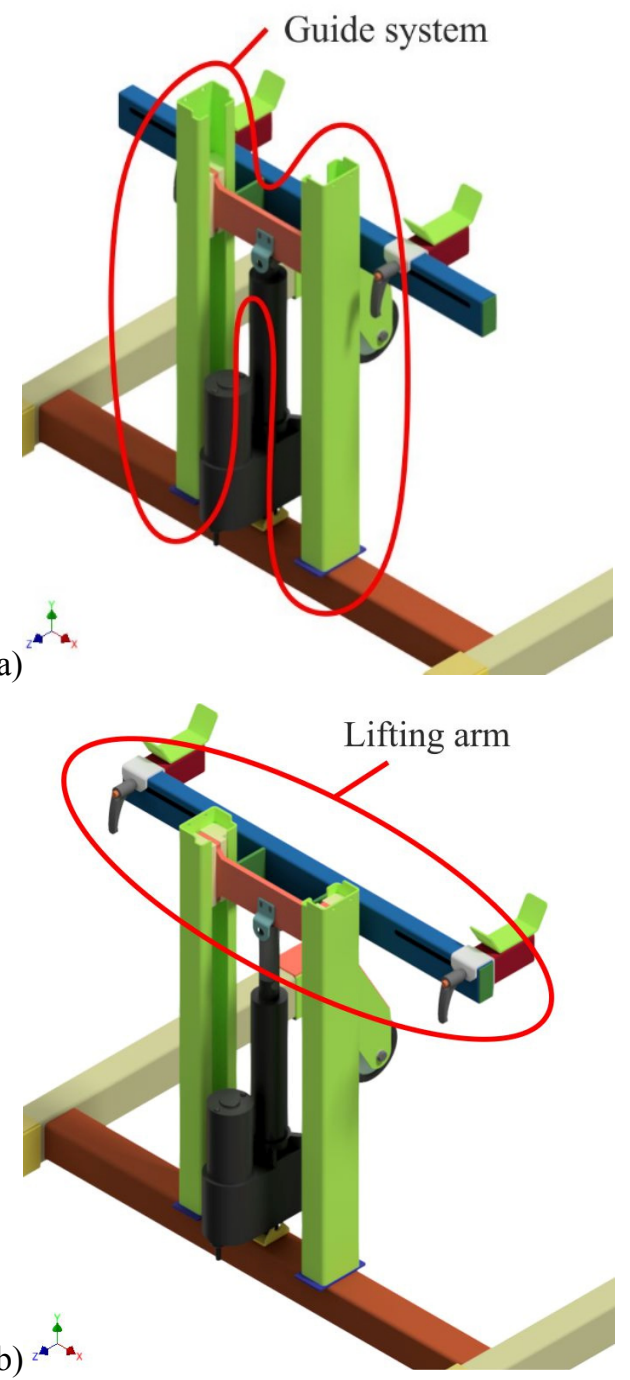

Figure 8. Lifting system: actuator retracted and grips in the closest position (a) and advanced actuator and grips in the expanded position (b).

When a signal is given to the actuator to advance, it is guided by the guiding system, consisting of a moving car with attached nylon blocks between two C-shape rails, raising the supports. The lifting arm is equipped with two supports, one on each side of the horizontal elements, to gain contact with the hospital bed and promote its lifting movement. To adapt to several bed designs, the supports slide horizontally to vary the distance between them, and to avoid regions of geometrical supporting impossibilities that the beds may have. To facilitate changing the supports' position, 
handle screws were placed to quickly fix and release them to the horizontal beam. These allow to swiftly adjust their position according to the available attachment points. In Figure 8 (a), the actuator and supports are retracted, while in Figure 8 (b) both are in the most advanced position.

\section{- Drive wheel structure}

This structure (Figure 9 a) was designed for the wheel to have a scissors movement, in addition to having a motor coupled to move the entire structure of the equipment, as well as the hospital bed. To perform this movement, the wheel will have a point of rotation (Figure 9 b) and a spring to restrict movement. The spring will serve to place the wheel in permanent contact with the ground, allowing the wheel to always have traction. It will also serve to reduce load impact to the equipment when hit by an object.

a)

b)

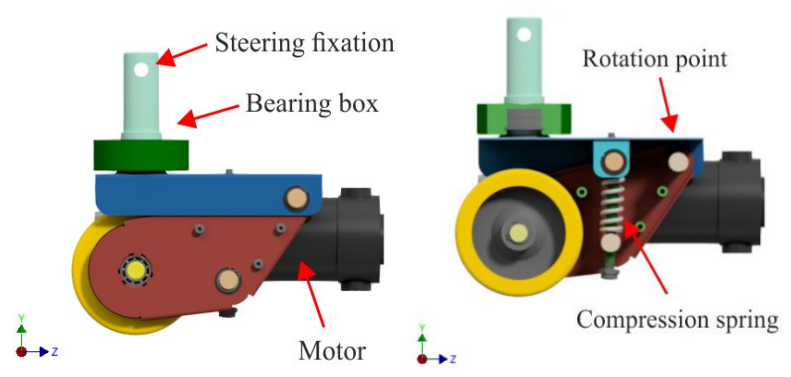

Figure 9. Drive wheel structure: system overview (a) and inside detail of the suspension system (b).

- $\quad$ Steering and commands

To control the equipment, an instrument panel was designed (Figure 10). As the equipment only moves and raises beds, only a switch to activate the electric actuator, a key switch (on/off) with LED to indicate when it is on, a battery charge indicator and an emergency button were placed. To move the equipment, there is an accelerator in the right handle, capable of moving the power wheel in both directions, thus making it able to mobilize the equipment back and forth.

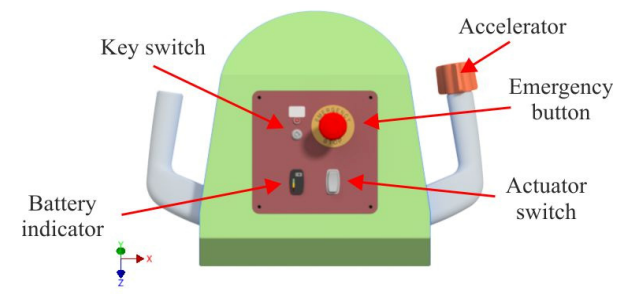

Figure 10. Instrument panel

Two Unit Pack Power S004-2 batteries were considered, on each side of the main frame, with the following characteristics: voltage of $24 \mathrm{~V}$, current intensity of $15 \mathrm{~A}$ and capacity of 29Ah. The equipment is driven using the handles incorporated in the instrument panel. As the connection between the instrument panel and the wheel is direct, and there are cables running through that connection to communicate from the interface to the controller, the turning angle had to be restricted to $180^{\circ}$. To make this movement restriction, a nylon backstop was placed at the base of the armor (inside), being tightened with the same screws as the bearing box that will be attached to the outside of the base of the armor, which makes the connection between the wheel structure and the steering system. A small steel block will be welded to the tube to prevent the steering from turning further when it touches the backstop (Figure 11).

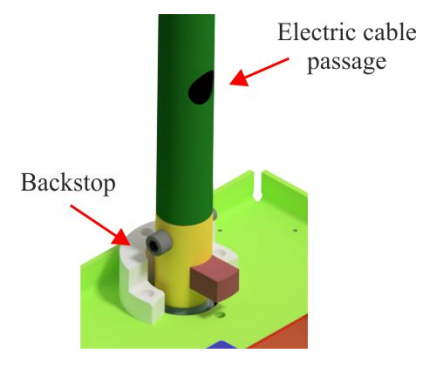

Figure 11. Backstop system to restrict the steering movement.

\subsection{Design requirements}

To design the proposed equipment, some parameters were requirements by the company and potential customers, which had to be met in this work. These parameters helped to define issues at the project level, namely:

- Maximum width of $1000 \mathrm{~mm}$, so that the equipment can pass through the doors (according to national regulations, the doors of rooms or wards should have a minimum useful width of $1.10 \mathrm{~m}$ );

- Adapt the equipment to the largest possible bed designs;

- Lift the bed up to $100 \mathrm{~mm}$ from the ground level to move the hospital bed;

- Equipment construction with easy access to all equipment surfaces, which should be smooth for easy cleansing;

- Load required to move the bed and equipment reduced to a minimum;

- Easy access to the interior for easier maintenance;

- Appealing design for hospital environment;

- Use of two lithium batteries specified by the company, with $24 \mathrm{~V}$ and $29 \mathrm{Ah}$;

- Maximum speed of the equipment of $4 \mathrm{~km} / \mathrm{h}$ and maximum working slope of $4 \%$.

\subsection{Main devices}

This equipment needs these 2 main components to operate: motor and actuator. The incorporation of these components allows the equipment to have mobility, lifting of the beds and control over the equipment. The electric motor is essential for this solution, since the objective of this equipment development is to remove the physical load from the health professional, when transporting the patient in hospital beds. As the motor is in an unprotected location, the motor must be compact and with a gearbox. This gearbox has an angular transmission and with a worm screw, requiring less free space for the motor/gearbox assembly when the steering is turned from side to side, because the motor is closer to the structure in which it is supported. The need to use 
a gearbox is due to the low speed at which the equipment shall circulate within a hospital service. The chosen motor has $250 \mathrm{~W}$ of power, with gearbox relation of 15 , torque of $10 \mathrm{~N} . \mathrm{m}$ and $24 \mathrm{~V}$ power voltage (Figure 12).

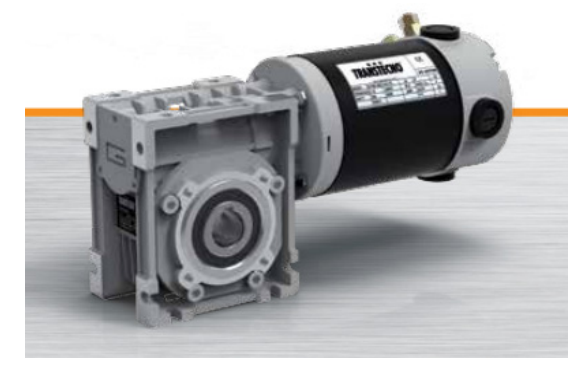

Figure 12. Motor Transtecno ECM 180/030 version 120/240/24E [21]

To lift a bed, a lifting system is required, in which case an electric actuator was selected, because it is the only viable option for a mobile system. To determine the actuator to put in the equipment, it was necessary to estimate the maximum load applied to the equipment and what is the maximum displacement intended for the actuator. As it is intended to lift a structure that supports a person, despite being at a small height from the ground, an extra safety factor must be considered. This safety factor is determined based in Directive 2006/42/EC of the European Union. Based in these prepositions, the electric actuator of Figure 13 was chosen, since it respects the design requirements, such as an extension of $100 \mathrm{~mm}$, a maximum force of $8.9 \mathrm{kN}$ and a $24 \mathrm{~V}$ motor. This actuator has an ingress protection code of IP65, to protect the users in case of liquid spill.

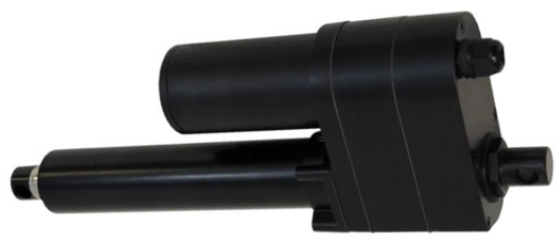

Figure 13. Progressive Automations PA-17 electric actuator [22]

\subsection{Component design}

For mechanical equipment to have safety and a longer service life, they must be designed according to safety criteria. In this equipment the von Mises yield criterion was used to verify the structure and relevant mechanical components for mechanical strength. For complex structures, it is necessary to use computational tools to help solve the design by numerical methods [23]. In this work, the Inventor ${ }^{\mathbb{B}}$ was used as modelling and design software by numerical methods, based on the FEM. For any design, it is necessary to determine the operating conditions. As only a static analysis was performed, only the worst conditions that the equipment would be subjected to during use were considered. Thus, a hospital bed with the maximum load capacity and selfweight was evaluated. To carry out the static study, it was necessary to simplify the model [24], removing all non-structural components such as wheels, motor, and steering system. In the case of the actuator, this element was replaced by a straight rod since it is not an element under study. However, it is essential for the load transmission in the structure. The materials were all defined as structural steel S235, except for the Nylon sliding blocks. Being a structure supported on wheels, these were either clamped or restrained to move in the ground plane, to emulate the real operating conditions.

Three types of loads were applied to the main structure: forces, remote forces, and self-weight. In the first case, the force is applied to a finite area, converting it to a uniform pressure, while in the second case, the force is applied at a point in space that will interact with a surface. For the self-weight, the force exerted by the mass of the structure was considered vertically and downwards. Thus, in the equipment, the self-weight and two forces were applied directly to the surface: the weight of the batteries and the weight of the bed in its maximum load capacity applied to the arm. Two remote forces were applied, corresponding to the two protection armors. Table 2 shows the position and loads applied to the structure, considering as origin the centroid of the main tube (Figure 7).

Table 2. Position and loads applied to the structure

\begin{tabular}{|l|l|l|l|l|}
\hline \multirow{2}{*}{ Description } & \multirow{2}{*}{ Force [N] } & \multicolumn{3}{|l|}{ Position [mm] } \\
\cline { 3 - 5 } & & $\mathbf{x}$ & $\mathbf{y}$ & $\mathbf{z}$ \\
\hline $\begin{array}{l}\text { Battery weight } \\
\text { (each) }\end{array}$ & 58.9 & - & - & - \\
\hline Bed weight & 3445.0 & - & - & - \\
\hline Structure weight & 336.1 & 0 & 178.3 & -70.7 \\
\hline Armor 1 & 53.2 & 0 & 248.7 & 150.9 \\
\hline Armor 2 & 14.5 & 0 & 604.9 & 5.0 \\
\hline
\end{tabular}

Two types of contacts were considered: bonded and sliding/no separation. The first type of contact prevents the surfaces from moving over each other, which means that all their degrees of freedom are restricted. In the second, surfaces that are in contact may have sliding movement in the plane of the surface, but movements in the normal direction of the surface (radial in the case of cylindrical surfaces) are prevented. Since the structure is almost fully welded, it was indicated that practically all contacts would be bonded. For all parts that needed sliding contacts, as in the case of the Nylon sliding blocks, a sliding/no separation type restriction was applied. In this case, the blocks always remain close to the guide, but they need to move vertically (Figure 14).
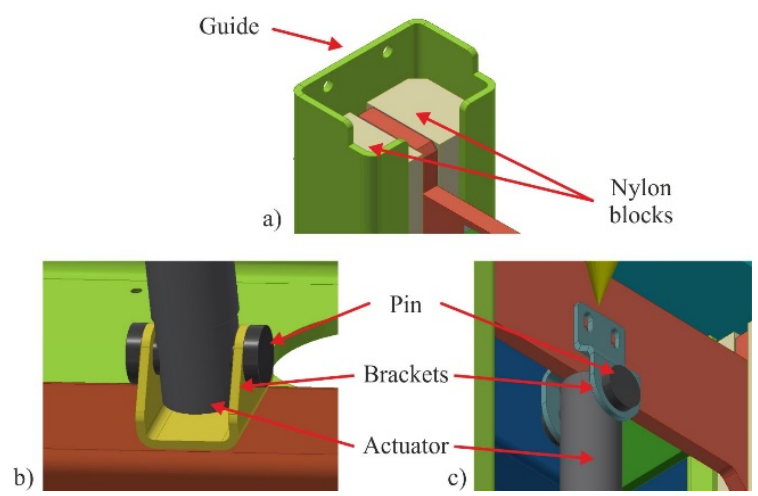

Figure 14. Identification of components that have a sliding/no penetration type contact (a), actuator (bottom end)/bracket (b) and actuator (upper end)/bracket (c) 
The software uses tetrahedral elements, and the size of each element is given according to the length of the component under analysis. This length is the one that the software finds most suitable for each component, with $10 \%$ of the component length being assigned as the average length that each element should have. The minimum size of each element is $20 \%$ of the average length. A mesh refinement analysis was conducted, and the displacements compared instead of stresses, because of stress singularity issues in sharp geometric change areas. To assess convergence, a relative variation between consecutive steps below 1\% was considered. This procedure is embedded in the software routines and is called adaptive refinement.

The safety factor was set to 1.5 , according to Directive 2006/42/EC, and the von Mises yield criterion is considered [25], leading to allowable stresses of 157 $\mathrm{MPa}$ (S235 steel) and $54 \mathrm{MPa}$ (Nylon). For the displacements, a maximum allowable of $1 / 200$ of the reference length for each axis was imposed. The $1^{\text {st }}$ analysis showed the existence of stress concentration, especially in the connection between the actuator and the lifting arm, making it necessary to redesign the connection (Figure 15). On the other hand, it was found that throughout the entire structure the stresses were much lower than the allowable ones. Therefore, it was possible to decrease the wall thickness in all the structure's parts (Figure 16). In the $2^{\text {nd }}$ analysis, with the reformulation of the bracket (to link the actuator and lifting arm) and the thickness reduction throughout the structure, it was possible to obtain a solution in which the installed stresses were lower than the maximum allowable stress. However, the displacement criterion was not respected. To overcome this issue, in the $3^{\text {rd }}$ analysis, the main tube was reinforced by increasing its thickness to reduce its torsion, which initially led to an excessive guide distortion. With this modification, it was found that both the maximum installed stresses, as well as the displacements, were below the maximum allowable (Figure 16). Table 3 shows that there was a $6.00 \mathrm{~kg}$ reduction in mass of the set consisting of the structure and lifting arm, corresponding to a reduction of $19.15 \%$. There was also a major reduction in von Mises equivalent stresses and increase in displacements, but within the maximum limits, giving a final solution that performs much better that the initial design.

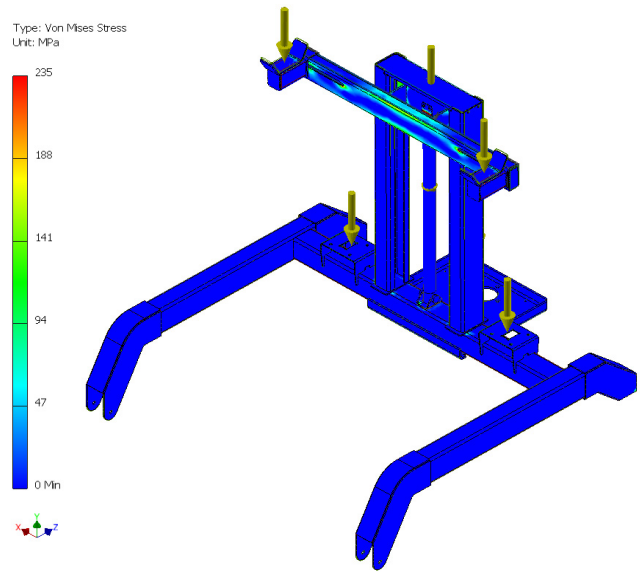

Figure 15. Equivalent von Mises stresses in the structure + lift arms set in the 1st FEM analysis

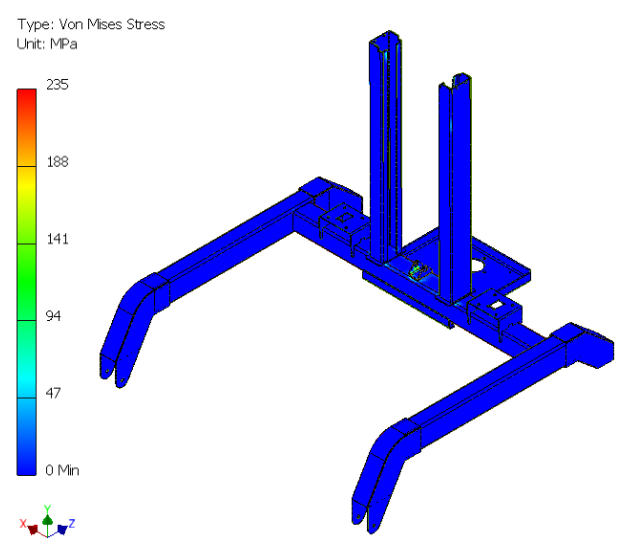

Figure 16. Equivalent von Mises stresses in the structure 3rd FEM analysis

Table 3. Comparison between the initial and final design solutions and respective differences in mass, maximum von Mises stresses and displacements.

\begin{tabular}{|l|l|l|l|l|l|}
\hline & Mass & $\boldsymbol{\sigma}_{m \kappa x}^{\text {van Mises }}$ & $\delta_{x}^{m \alpha x}$ & $\delta_{y}^{m a x}$ & $\delta_{z}^{m a x}$ \\
\hline & {$[\mathrm{kg}]$} & {$[\mathrm{MPa}]$} & {$[\mathbf{m m}]$} & {$[\mathbf{m m}]$} & {$[\mathbf{m m}]$} \\
\hline Initial & 31.33 & 496.8 & 0.1105 & 0.5223 & 2.431 \\
\hline Final & 25.33 & 162.0 & 0.3199 & - & 2.746 \\
\hline Difference & -6.00 & -334.8 & 0.2094 & - & 0.315 \\
\hline $\begin{array}{l}\text { Difference } \\
{[\%]}\end{array}$ & -19.15 & -67.4 & 189.50 & - & 12.96 \\
\hline
\end{tabular}

In the drive wheel structure, as in the main structure, some components have been replaced by simpler representations, such as the motor shaft and support bearings. The structure only has two attachment points: the wheel that is in contact with the ground, and the bearing support in contact with the steering system and the main structure (Figure 17). As the wheel is the component that is moving in relation to the structure, it was defined that it would be the part that is in contact with the steering system to have movement restriction, which was applied to the contact surface with the bearings (Figure 17). The external load was applied to the wheel axis.

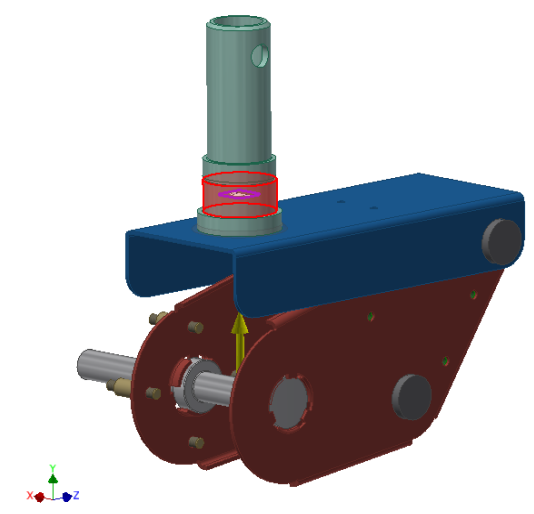

Figure 17. Movement restriction of the drive wheel structure

Table 4. Position and values of applied loads to the structure

\begin{tabular}{|l|l|l|l|l|}
\hline \multirow{2}{*}{ Description } & \multirow{2}{*}{ Force [N] } & \multicolumn{3}{|l|}{ Position [mm] } \\
\cline { 3 - 5 } & & $\mathbf{x}$ & $\mathbf{y}$ & $\mathbf{Z}$ \\
\hline$R_{\text {DriveWheel }}^{y}$ & 124 & - & - & - \\
\hline Motor weight & 45.13 & 91.0 & -57.6 & 94.4 \\
\hline Self-weight & 28.03 & 57.7 & -39.4 & 4.9 \\
\hline
\end{tabular}


This structure has two applied external loads: the motor's weight and the structural reaction force, which add to the self-weight (Table 4; the coordinate system origin lies at the intersection between the steering system axis and the top horizontal plate of the wheel set). In the contacts between components, it was defined that all shafts have sliding/no penetration relations, except for the shaft that fixes at the top of the spring guide, since the guide is threaded to the shaft. Thus, in this case, a bonded contact has been assigned. To represent the spring, a spring type contact was considered, with a stiffness constant $k$ of $47.7 \mathrm{~N} / \mathrm{mm}$.

The mesh refinement parameters were considered identical to the former analysis. For this structure, only one analysis was performed, since only the stresses were analyzed, as this structure is articulated. The results showed that the entire structure has low stresses, lower than $70 \mathrm{MPa}$ (Figure 18). As the entire set is fabricated from steel, safety is achieved since the von Mises equivalent stress is always lower than $157 \mathrm{MPa}$. It can thus be concluded that there is room for improvement and material reduction. However, since the sheet metal is $2 \mathrm{~mm}$ thick and is supported on shafts, connected by bronze bushings, it was decided to leave the geometry as is to prevent fast wear in the brushings, as this connection is mostly in shear and the low thickness would increase the shear stresses. The displacements in the structure were relatively low and respected the used criterion for maximum displacements.

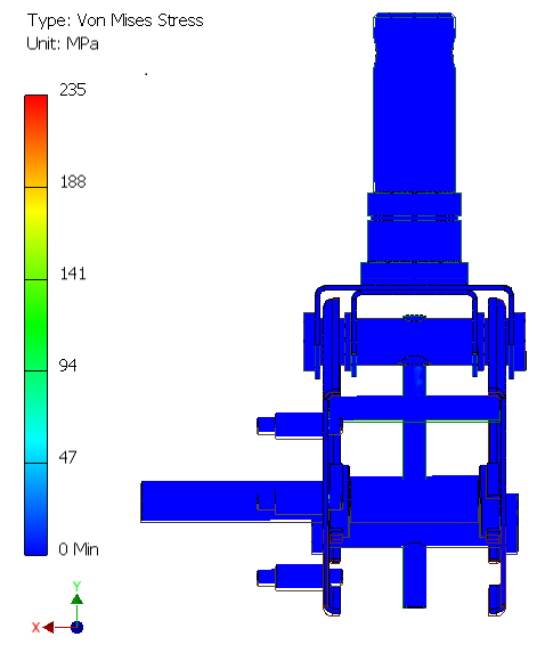

Figure 18. Equivalent stress of von Mises in the drive wheel structure

\section{CONCLUSIONS}

The main goal of this work was to design an equipment for hospital bed movement, including a FEM analysis for validation and optimization purposes. The design goals were initially defined, and different solutions were equated. In the brainstorming sessions, different restraints were posed, leading to the proposal of two tentative design solutions. Selection was accomplished to an equipment with four swivel wheels and a driving wheel linked to a steering wheel and instrument panel, mounted on a frame structure built from rectangular profiles. The driving and actuator systems, as well as the frame structure, were designed after establishing the equipment requirements. With this in mind, a $250 \mathrm{~W}$ motor coupled to an angular transmission gearbox and an $8.9 \mathrm{kN}$ electric actuator were selected to power the equipment. The frame and drive wheel structures were finally designed by the FEM, by imposing strength and displacement restrictions at the start of the process, after performing a mesh refinement convergence analysis. While the frame structure analysis resulted in two improvements to the initial proposal, leading to an optimized solution that improved maximum stress and weight, the drive wheel structure was not changed from the initial design due to stability and brushing wear issues. In the end, with this work, an automated equipment was proposed and will enter the prototype construction phase in the company before mass production is made viable.

\section{REFERENCES}

[1] Lupton, D.: Medicine as culture: illness, disease and the body, Sage, Newcastle, 2012.

[2] Lee, S.J., Kang, K.J. and Lee, J.H.: Safe patient handling legislation and changes in programs, practices, perceptions, and experience of musculoskeletal disorders by hospital characteristics: A repeated cross-sectional survey study, Int J Nurs Stud, Vol. 113, pp. 103791, 2021.

[3] Caponecchia, C., Coman, R.L., Gopaldasani, V., Mayland, E.C. and Campbell, L.: Musculoskeletal disorders in aged care workers: a systematic review of contributing factors and interventions, Int J Nurs Stud, Vol. 110, pp. 103715, 2020.

[4] Kim, S.S., Okechukwu, C.A., Dennerlein, J.T., Boden, L.I,, Hopcia, K., Hashimoto, D.M. and Sorensen, G.; Association between perceived inadequate staffing and musculoskeletal pain among hospital patient care workers, Int Arch Occup Environ Health, Vol. 87, pp. 323-30, 2014.

[5] Wang, H. and Kasagami, F.: A Patient Transfer Apparatus Between Bed and Stretcher, IEEE Trans. Syst. Man Cybern. Syst., Vol. 38, pp. 60-7, 2008.

[6] Fujida, M.: A MIZUHO Torancemover system used for patient transfer in hospital, JJMI, Vol. 64, pp. 517, 1994.

[7] Bourke, J. and Roper, S.: The influence of experiential learning on medical equipment adoption in general practices, Health Policy, Vol. 118, pp. 37-47, 2014.

[8] Organization, W. H.: Medical devices: managing the mismatch: an outcome of the priority medical devices project: World Health Organization, 2010.

[9] Davcev, D. and Jakimovski, G.: Ergonomics Design of Healthcare NFC-based System, Procedia Manufacturing, Vol. 3, 5631-8, 2015.

[10] Dekker, S.: Complexity, signal detection, and the application of ergonomics: Reflections on a healthcare case study, Appl. Ergon., Vol. 43, pp. 468-72, 2012.

[11] Kucera, K. L., Schoenfisch, A. L., McIlvaine, J., Becherer, L., James, T., Yeung, Y-L., Avent, S. and Lipscomb, H. J.: Factors associated with lift equipment use during patient lifts and transfers by 
hospital nurses and nursing care assistants: A prospective observational cohort study, Int. J. Nurs. Stud., Vol. 91, pp. 35-46, 2019.

[12] Graham, P. L.: Increasing Patient and Student Nurse Safety Using Safe Patient Handling, Clin. Simul. Nurs., Vol. 45, pp. 24-7, 2020.

[13] Osvalder, A-L. and Bligård, L-O.: Usability and ergonomics in medical equipment, in: Proceedings of the 39th Nordic Ergonomic Society Conference, Göteborg, pp. 1-5, 2007.

[14] Thompson, P. W.: Safer design of anaesthetic equipment, Br. J. Anaesth., Vol. 59, pp. 913-21, 1987.

[15] Tonks, A.: Patient safety: Safer by design, BMJ, Vol. 336, pp. 186-8, 2008.

[16] Das, B., Wimpee, J. and Das, B.: Ergonomics evaluation and redesign of a hospital meal cart Appl. Ergon., Vol. 33, pp. 309-18, 2002.

[17] McAnyana, K. B., Kallon, D. V. V. Tartibu, L. K.: Towards the Design of the OTS Ceiling Suspension Unistruts of the XR-646 Medical Equipment, Procedia Manuf., Vol. 35, pp. 207-15, 2019.

[18] Kurebwa, J. G. and Mushiri, T.: Passenger car safety and emergency healthcare: a literature review, Procedia Manuf., Vol. 35 ,pp. 35-49, 2019.

[19] Castelôa, L., Luís, S., Romeiro, T. and Oliveira, I.: Prevalence of musculoskeletal injuries related to nurses' work: Integrative review (Prevalência das lesões músculo-esqueléticas relacionadas com o trabalho dos enfermeiros: Revisão integrativa), RIIS, Vol. 2, pp.63-74, 2019.

[20] Daniell, N., Merrett, S. and Paul, G.: Effectiveness of powered hospital bed movers for reducing physiological strain and back muscle activation Appl. Ergon., Vol. 45, pp. 849-56, 2014.

[21] Transtecno: Gearmotor DC worm gear NDCM ECM, Italy, 2020.

[22] Automations, P.:, Heavy duty linear actuator, Arlington, 2020.
[23] Abdullah, O., Schlattmann, J. and Pireci, E.: Optimization of shape and design parameters of the rigid clutch disc using FEM, FME Transactions, Vol. 41, pp. 317-24, 2013.

[24] Momcilovic, D., Subic, A., Atanasovska, I. and Mitrovic, R.: Combined load simulation vs component loads simulation in machine design: A case study, FME Transactions, Vol. 42, pp. 48-55, 2014.

[25] Odabasi, V., Maglio, S., Martini, A., Sorrentino, S.: Static Stress Analysis of Suspension Systems for a Solar-Powered Car, FME Transactions, Vol. 47, pp. 70-5, 2018.

\section{КОНЦЕПТ И ДИЗАЈН АУТОМАТИЗОВАНОГ УРЕЂАЈА ЗА ЗДРАВСТВЕНУ ОПРЕМУ}

\section{Н.М.С. Фарија, Р.Д.С.Г. Кампилхо, Ф.Ј.Г. Силва, Л.П. Фереира}

Премештање тешко покретних пацијената, транспорт носила, болничких кревета и колица доводе до физичке исцрпљености здравствених радника. Недостаје опрема која би помогла овим професионалцима при премештању пацијената који су у болничким креветима или на носилима. Циљ рада је да се дизајнира опрема која ће олакшати померање пацијената са кревета на носила или кретање кревета у болничким просторијама. Приказана је и диверзификација модела болничких кревета са могућношћу адаптације опреме за сваки тип кревета. Процес дизајнирања укључује и неколико ФЕМ анализа за евалуацију структуре уређаја и оптимизацију конструкције у циљу смањења трошкова и тежине опреме. Успешно је дизајнирано оптимално аутоматизовано решење које може да побољша услове рада у индустрији здравствене опреме. 